\title{
INTERFACES DA CARNE: Entrevista com Olivier de Sagazan
}

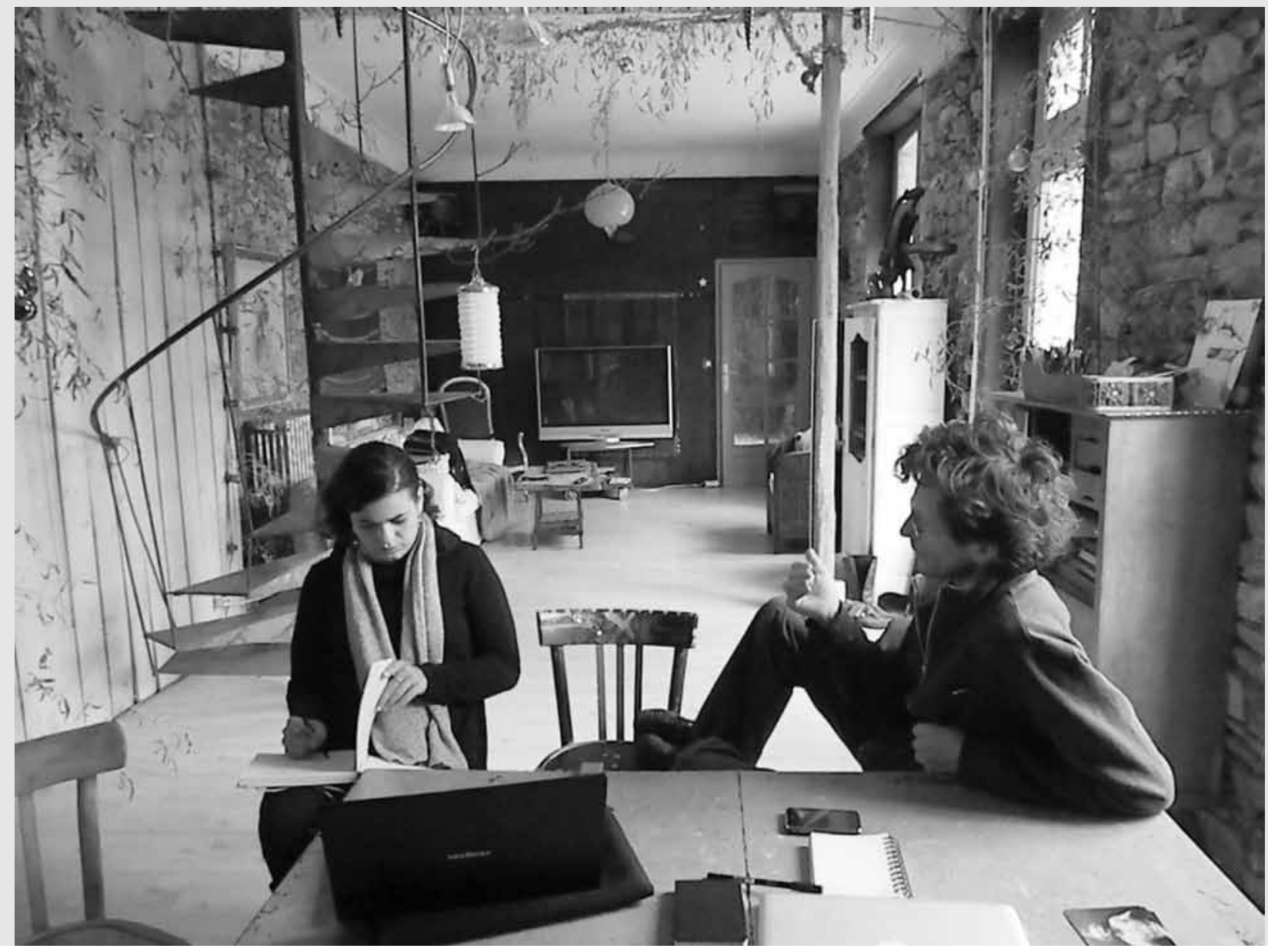

Entrevista com OLIVIER DE SAGAZAN, fevereiro de 2011, casa do artista em SAINT-NAZAIRE,

França. FOTÓGRAFO: George Cordeiro (Ghel Nikaido). Arquivo pessoal da autora.

Elisa Schmidt ${ }^{1}$

Olivier de Sagazan ${ }^{2}$

Tradução de Telma Duarte Transliteração de Paulo Da Cruz

1 Esta entrevista é parte documental da pesquisa de Elisa Schmidt. Mestranda bolsista da CAPES, integrante do Programa de Pós-graduação em Teatro da UDESC, no qual pesquisa a desfiguração em arte a partir das obras de Olivier De Sagazan.

2

ODS expôs em muitas galerias, entre elas: Marie Vitoux, em Paris; Grand'Rue, em Poitiers . Entre as bibliografias escritas sobre suas obras constam os livros: Transfiguration - Edicãa Democratic bocks; Le Fantôme dans la machine - Edição Universitaire D'Angers ; Carnet D'atelier - Edição Mémoire Vivante ; Etres Chairs - Edição Nazairienne ; Quand le visage perd sa face - La défiguration en art / La Violence en Art - Editição Vitoux. Participou também do filme Samsara de Ron Frick - realizador de Baraka. Mais informações sobre 0 artista e suas obras em : http://nefdesfous.free.fr/

3 Estudou artes plásticas na França. É professora de francês e tradutora autodidata.

4 Nascido em França, ministra aulas de francês no Brasil há mais de cinco anos. É tradutor autodidata.
Elisa Schmidt (E.S.): Quem é Olivier De Sagazan? Você poderia se apresentar em algumas linhas: sua origem familiar, seus estudos, seu percurso de artista?

Olivier De Sagazan (O.D.S.): Eu nasci na África, mas não sou africano. Eu tive sorte, como dizia um de meus amigos congoleses. Fui concebido entre os dois rios, entre Bordeaux e Brazzaville. Na época, a viag em levava seis meses para ir de barco de uma cidade a outra. Na minha cabeça tinha, frequentemente, esta ideia de ter sido concebido entre estes dois rios: entre o mundo ocidental e o mundo africano. Meu trabalho geralmente é um olhar desta cor- 
respondência dos dois rios e é por isto que eu gosto, às vezes, das questões que colocam os filósofos ocidentais sobre a questão da razão, do pensamento, etc... Todo o idealismo que pode nascer na Europa... Mas ao mesmo tempo, eu estou muito próximo do sentimento africano, do toque africano. A questão do toque para mim é essencial. Eu tenho a impressão que no pensamento dos ocidentais, separamos sempre a mente do corpo. Somos sempre uma forma de dualismo e eu não suporto este dualismo. Para mim, o corpo e a mente são uma mesma coisa. Eu sou espinosista sobre isto e isto vem, sem dúvida talvez, deste amor ao mesmo tempo pela África e pelo ocidente. Penso um pouco como Aristóteles, “o fundamento da alma é o toque". O fundamento da alma é o toque, isto quer dizer, que tudo procede do toque. Mesmo os pensamentos, os maiores, são relacionados com as questões do toque.

\section{E. S.: E você estudou um pouco de arte ou foi por experiência?}

O.D.S.: Não, sou autodidata. Eu sou formado em biologia e foi depois que cheguei à arte. De fato, eu tive a chance de fazer minha cooperação no Camarões. $\mathrm{Na}$ época, os jovens deviam fazer um ano de quartel ou dois anos de exército no estrangeiro. Eu preferi ir para o estrangeiro, assim, eu não precisava usar boné e roupas militares (risos). E lá eu fui como professor de biologia durante dois anos. Era muito interessante, muito enriquecedor. [...] Fui levado, então, para Camarões numa aldeia chamada Loum. Assim, lá, eu era professor de segunda fase terminal ${ }^{5}$ de biologia, de ciências naturais. Eu tive sorte porque eu me determinei a só fazer biologia. Mas antes de partir, eu passei por Amsterdam, na Holanda. E eu reencontrei Rembrandt, eu estava no grande museu de Amsterdam onde tinha muitos, muitos autorretratos dele. Eu fiquei fascinado por Rembrandt, o pintor. E tive um choque, quer dizer, quando vi as pinturas de Rembrandt, eu fiquei

\footnotetext{
5 Fase terminale corresponde ao último ano do ensino médio no Brasil (Nota tradutora).
}

em frente, fascinado. Tive a impressão de que eu poderia fazer a mesma coisa. Eu olhava todas as pinceladas, conforme elas foram dadas para fazer um rosto. Então, tive a impressão de que eu poderia fazer a mesma coisa. Estava muito orgulhoso. Mas, eu saí de lá e fui para um café (bar). Eu via tudo em forma de pintura. Via tudo como uma pintura. E foi de repente, eu via tudo em forma de pintura, tudo estava na forma de toque como isto. E eu achei isto maravilhoso. Então, eu me disse que: talvez um dia eu seja um pintor também. E, então, o interesse de fazer a cooperação, é que você parte de sua casa, você viaja a $7.000 \mathrm{~km}$ de distância de sua casa enquanto você tem 23 a 24 anos. E é muito importante sair de casa quando temos esta idade, porque nos distanciamos. Nos distanciamos em relação as coisas e as pessoas, é uma distância em relação à um conformismo. Nos distanciamos em relação ao movimento ao qual fomos colocados. E olhamos as coisas do exterior e nos dizemos: "É feito para mim?", “Eu realmente vou continuar lá?". Na realidade, em Camarões, eu comecei a refletir, eu me disse: "Biólogo, não é necessariamente um mundo de pensamento que corresponde a mim". Eu fantasiava demais para chegar imediatamente a uma visão sintética. $\mathrm{O}$ biólogo, no princípio, vai extrair, vai levar coisas e então vai fazer extrações, análises e análises. E, em seguida, pouco a pouco, vai reconstruir o quebra-cabeça, vai começar a colocar os conceitos, as ideias etc.. Mas, na realidade, eu comecei a estudar biologia na esperança de tentar entender o que era a vida. Eu tinha uma visão um pouco como Jacques Monod, que escreveu "O acaso e a necessidade". Tu conheces, talvez, este livro. Um grande livro. E que é assim, uma aproximação muito sintética, muito ambiciosa do processo da vida. Ou então a "Nova Aliança", de Ilya Prigogine. E todos esses livros tinham me estimulado, mas na realidade, quando você é um biólogo, é obrigado a ser bem minucioso em fazer coisas muito, muito pequenas. $\mathrm{Na}$ realidade não era para mim. Eu estava muito mais na metafísica do que na filosofia para fazer isto. Finalmente, eu ficaria triste, eu sofre- 
ria muito. Entretanto, a pintura te permite rapidamente te colocar grandes questões e de atacar o grande problema.

\section{E. S.: O que é o inominável do qual falas?}

O.D.S.: O inominável do qual falo é a ideia que eu sou dirigido, quer dizer que sou empurrado a cada momento pela resultante destas duas forças. Mas meu movimento é como ter as forças externas, as forças internas aqui. E aqui, tem algo que chamamos o inominável, que chama o " $\mathrm{si}^{\text {" }}$. No momento em que falo esta palavra, este movimento de meu ser é a resultante das forças ao mesmo tempo externas, internas e algo que me empurra sempre para frente. Quer dizer que, se a vida não fosse estas duas forças, a vida seria uma imobilidade. Quer dizer, aqui tens este caderno que está sobre a mesa. Tens uma força que empurra o caderno, o caderno empurra sobre a mesa, mas isto permanece em equilíbrio. A vida não é isto. É que a vida, permanentemente, tem a energia que sai, e a energia que entra. E como tens a energia que sai porque deves aquecer o teu corpo, deves fazer muitas coisas, é necessário, portanto, mover-se permanentemente, é necessário, permanentemente, reencontrar o equilíbrio. A vida é um desequilíbrio permanente. E como estás todo o tempo em desequilíbro e deves todo o tempo procurar o teu equilíbrio, é neste desequilíbrio fundador e nesta procura permanente de equilíbrio, onde está o movimento da vida, que chamo de inominável. Mas quando digo isto, faço justamente uma abordagem fisicalista. É física.

Agora, sobre o plano psicológico, o inominável é algo ainda mais complicado, visto que este inominável é este pensamento que tenta permanentemente se retomar a si mesmo. É este pensamento do pensamento. Vês? [...] Quer dizer que, permanentemente, digo algumas coisas, mas retomo a mim mesmo porque não é exatamente isto. E no momento em que me desenvolvo para melhor tentar me exprimir, sou de novo outra coisa. Então, eu tento retornar e nunca consigo me perceber eu mesmo. Então, o inominável é este movimento que te atra- vessa, é o movimento que atravessa o teu corpo e que te faz avançar, mas é um movimento do qual tu não podes falar porque seria necessário conseguir dizer para poder concretizar. Então, a cada vez, fazes parte deste movimento. Portanto, não podes falar exatamente sobre isto. Tu és todo o tempo dependente disto. Tu és um só com este movimento, assim para conseguir realmente falar sobre isto, seria necessário poder dizer. Somos um pouco flagrados neste pequeno problema de auto-referência. Portanto, somos pegos neste fenômeno de auto-referência que faz com que o inominável seja algo de perceptível, mas que nunca é descritível. E quando lês o "Inominável" de Samuel Beckett, permanentemente vês isto, percebes este movimento onde o escritor tenta, pela sua escrita, compreender a si mesmo, mas nunca consegue. É permanentemente como numa forma de cambalhota assim, vês? De passos largos.

\section{E.S.: Quais são as suas referências teóricas para as suas criações? Beckett $e$ quais outras?}

O.D.S.: $\mathrm{O}$ pintor a que mais me refiro é Francis Bacon, certamente. E Alberto Giacometti também, penso que é muito próximo dele. Mas porque um como o outro, sentimos uma onipresença da mão. A mão é o ser muito, muito forte no caso de Giacometti, sou mesmo mais interessado por suas pinturas e por seus desenhos do que por suas esculturas. Acho que as suas esculturas se repetem um pouco. A primeira escultura bem esquelética, etc., era bem vista. Enquanto que suas pinturas, seus desenhos, tem uma vibração extraordinária. Realmente é "brrr" (suspiro), é como uma coisa... e estamos às vezes no movimento e na imobilidade e é muito, muito bonito.

Em Bacon, o que é fascinante é a paginação, são as cores, é esta tensão extraordinária entre o assunto, a personagem e um ambiente que lhe é metáfora do real, uma forma de analogia do real, mas fixada em duas dimensões. E então, este surgimento de um motivo em três dimensões explosivas, porque todo o tempo desfigurado, mas 
antes com as diferentes forças, etc. Mas, somos seres naturalmente muito complexos e ao mesmo tempo fisiológicos, com uma fisiologia limpa, uma anatomia, uma forma, uma psicologia, uma história, etc. Portanto, a identidade se declina após um nível diferente. E, portanto, o nível, mas todos os níveis - eu, como artista - me interessam. Ou seja, que o nível da forma me apaixona, ou seja, a anatomia me interessa muito, a forma me interessa. Mas penso que tudo está em interação. Ou seja, que a anatomia, a forma, ela própria, resulta de certa maneira, de um impulso interno, de uma energia interna. Portanto, a identidade de um indivíduo é todo este conjunto de forças que constituem o organismo, ao mesmo tempo das forças fisiológicas, ao mesmo tempo das forças, tudo o que constitui a herança cultural etc. Portanto, não posso te responder assim, diretamente, o que é a identidade, porque é como o inominável. Está muito próximo. Esta identidade, em todo caso, para mim, se caracteriza por um desejo permanentemente de regresso sobre si e da tentativa de compreender quem eu sou. Eu diria que é pelo qual me identifico, é por este desejo permanente de tentar fazer um retorno sobre mim. E, portanto, todo meu trabalho é mesmo a expressão deste desejo [...].

Tenho sempre este sentimento que algo em nosso pensamento, da nossa consciência, tinha acesso intuitivamente a algo mais que justamente não se podia nomeá-lo. Quer dizer que se tinha uma espécie de sentimento, mas que não se chegava à... É mais uma teologia negativa, ou seja, que se chegava a isto de maneira negativa se dizendo: “Não é possível que eu esteja num mundo, num conjunto e um pequeno ponto entre mil milhões de outros pequenos pontos e que eu tenha a percepção do conjunto". Ou seja, que tenho como de mim mesmo, uma percepção de algo de caótico, de algo incongruente. Ou seja, que tenho a percepção de mim mesmo perante o resto do mundo, que algo não vai bem. Compreendes? [...]

Onde um sentimento de estranheza de mim mesmo em relação ao mundo: Um estranho, tu és um estranho num país. De onde vem a sensação de ser sempre um es- tranho no mundo? Portanto, é um pouco a percepção fundadora que eu poderei te dizer de mim mesmo. E me digo: Como se faz para que eu tenha esta sensação de estranheza se tudo é normal? Por que tenho esta sensação? Por que tenho isto em mim? É um mau ajustamento da máquina genética? $\mathrm{Ou}$ é outra coisa? É uma máquina genética que tem um sistema, que está permanentemente em abertura e que me faz ter este olhar não fechado sobre mim mesmo? Não sei muito bem! Mas, portanto, não consigo saber se esta sensação de estranheza vem justamente desta mecânica genética ou se é uma realidade ontológica e mesmo matemática, que faz com que tenha sido descrita matematicamente no teorema de Gödel. Gödel é um matemático que mostra que em todo o sistema formal, há sempre um inacabado. $\mathrm{Ou}$ seja, que há sempre um inacabado, ou seja, que há sempre um ponto insolúvel, há sempre uma equação insolúvel. E para resolver esta equação, será necessário construir um sistema formal superior a este. Tinhas um sistema A, é preciso se por um sistema B que o englobe para poder responder aos pontos de interrogações. É isto que se chama teorema de Gödel. Portanto, toda minha questão é talvez que eu sou um sistema formal como descreve Gödel. E que meu organismo, certamente, não pode responder à questão de sua identidade sem se preocupar, sem se angustiar. De onde vem a angústia metafísica: "Quem eu sou, por que não posso responder o que eu sou?". E de onde vem a ideia que só uma resposta vem do exterior e, de onde vem a invenção de todas as religiões.

E.S.: E como você faz a ligação entre civilização primeira ${ }^{6}$ e o contemporâneo? Porque a "performance" é arte contemporânea...Eu questiono se isto é sagrado ou se é profanação - quando pego um pouco da civilização primeira e faço "performance".

$\mathrm{Na}$ arte, várias pessoas utilizam o sacrifício para falar da vida. Não sei se é sa-

6

Civilização primeira está referenciando as civilizações tribais, indígenas, africanas (Nota da autora). 
grado ou se é uma profanação. Eu sempre me questiono, porque penso que muitos artistas se cortam, se angustiam... porque são doentes. Há um pouco de dor na sua relação com o mundo. A vida é sagrada, a vida é muito bonita, mas para eles é uma lamentação. Não sei ... o que você pensa sobre a relação entre a arte sagrada e a profanação?

O.D.S.: Sim. É uma grande pergunta. No momento em que fazia minhas primeiras "performances", eu me fazia uma perfusão. Isto tinha um caráter sagrado, o sentido é ambíguo. Não queria, sobretudo, estar numa representação teatral. É uma maneira de dizer: "Isto não é um jogo. Isto é o meu corpo e então isto é um instinto único e singular". Eu sabia que colocando uma agulha numa veia, me faria muito medo, eu estava imediatamente aqui e agora, em algo de único, porque com o corpo, não se pode mentir. No teatro pode-se mentir. Pode-se dizer não sei muito o quê, enquanto que com o corpo não se pode mentir. Então, quando se enfia um ferro numa veia, não se pode mentir. Se tu enfias em si mesmo um ferro numa veia, quer dizer que terás medo, podes te contaminar com uma bactéria no coração, podes te fazer mal, etc. Teu próprio sangue sai, quer dizer que tu estás às vezes num momento profano, mas para exaltar o sagrado. Compreendes? Quer dizer que em um dado momento, tu começas a consumir um pouco teu corpo, mas é apenas para exaltar um pouco mais o caráter miraculoso do corpo. E no momento do teu corpo vivo. E, portanto, fazendo isto, eu sabia que eu estava imediatamente no momento mesmo em que o fazia, eu estava aqui, completamente aqui. Eu não estava num ensaio de alguma coisa. É uma maneira, para mim, de escapar do teatro. É realmente para mim, a separação entre a "performance" e o teatro. $\mathrm{Na}$ "performance", tens um compromisso do corpo que faz com que este corpo esteja realmente num momento de vida. Ele não está numa representação. Compreendes?

\section{E. S.: Sim.}

O.D.S.: E eu fazia isto em todas as minhas primeiras "performances", eu fazia isto seis ou sete vezes, porque que-

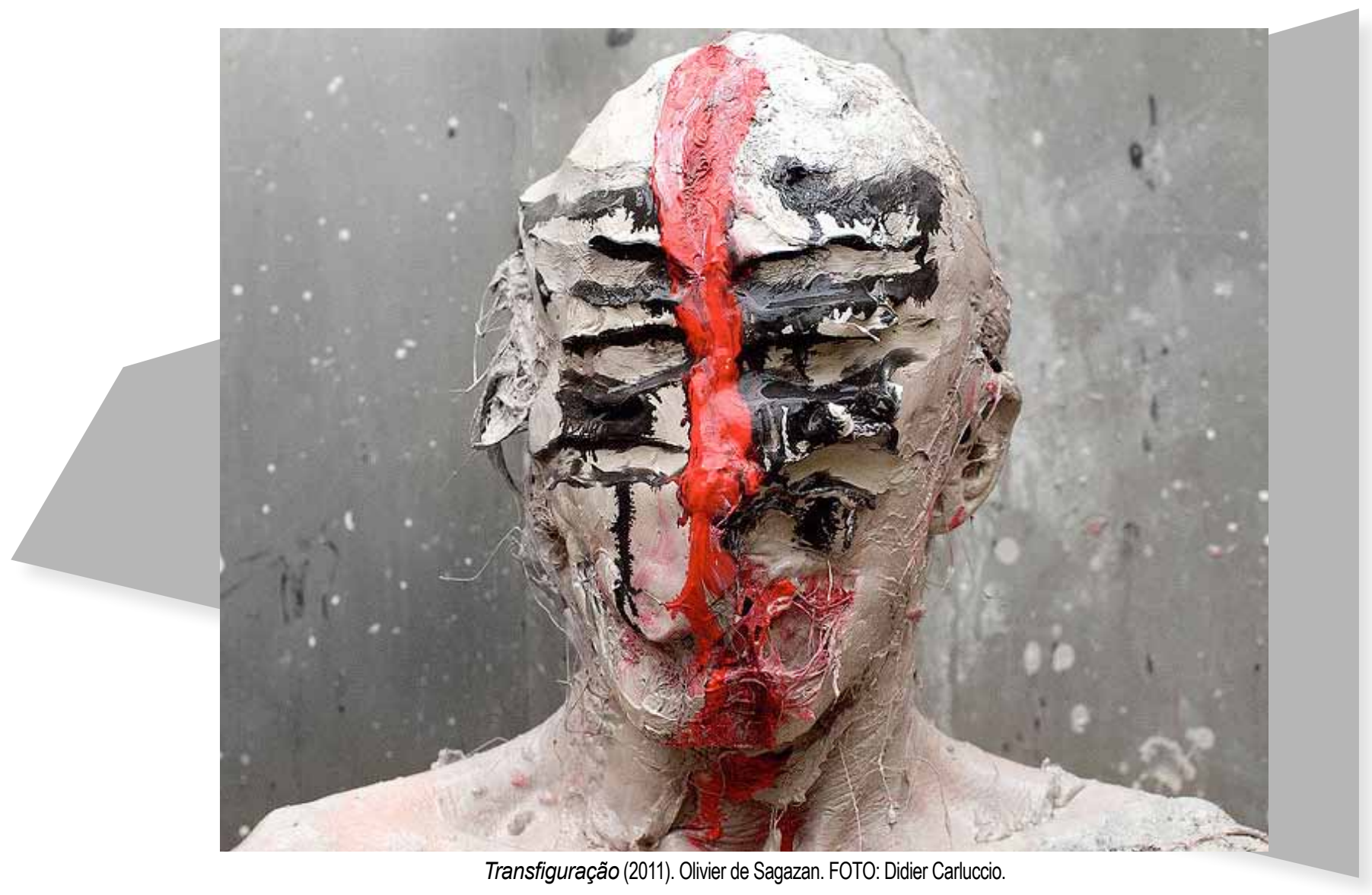


ria realmente estar completamente aqui, como você está, completamente em frente do teu quadro, quando após uma hora de trabalho vês que... durante uma hora tu trabalhas após um momento dado, pouf! Tu estás realmente em conexão, todo o teu cérebro com o quadro. Quando chegas ao ateliê, no começo giras como um animal numa gaiola: "O que vou fazer?" Então começas a preparar os teus pinceis, fazes 150 coisas e fazes nada. Estás justamente se conectando com a tua prótese que é a tela. A tela é uma prótese. Tu estás te conectando por toda parte e ao fim de uma hora tu estás dentro. É necessário uma hora para estar conectado num quadro. Quando tu chegas à cena e que tu te colocas nisto, não é uma hora, é em 2 segundos - você está lá. E é isto o interessante se queres arte. É a razão pela qual eu fazia isto. Agora não tenho mais necessidade, agora tenho a impressão que rapidamente estou dentro. Mas era uma maneira para mim de escapar, para entrar num total compromisso imediatamente.

E. S.: Richard Schechner é um pesquisador que fala de "performance"... Ele é muito estudado no Brasil e nos Estados Unidos. Ele fala que toda a vida é uma "performance". Todas as pessoas são "performers". E que a vida cotidiana é "performance"... Eu penso que a identidade é um personagem. Ele fala disto... E quando uma pessoa propõe-se a se colocar numa situação de "presentação" é também um teatro. E se você pensa conscientemente: - eu vou me cortar - é fazer teatro também. É a fronteira entre o teatro e a "performance". Quando me ponho no lugar dos espectadores, isto é teatro. Mas enfim, o que problematizo é a fronteira entre a "performance" e o teatro...

\section{O.D.S.: Qual é a fronteira entre a "per- formance" e o teatro? \\ E.S.: A vida é "performance".}

O.D.S.: Sim, é deste ponto de vista. De qualquer modo - creio que te falei um pouco ontem. É toda a grande discussão entre Diderot e Artaud. Diderot pensa que se é realmente um bom ator, quando não se submete, de forma alguma, ao que se vive, mas que se será ao contrário de interpretar com todas as cordas como um marionetista. Enquanto, que Artaud, pensa que só a marionete que vive o que ela vive é realmente sugestiva, capaz de exprimir grandes coisas. Mas o medo de ir ainda mais longe, ou seja, que se pode dizer que se vai ler um texto vivendo-o totalmente e chorando realmente. etc. Ou, estando realmente, totalmente, movimentado pelo que se vive. Portanto, pode-se ainda ir mais longe dizendo: "Vou dizer algo, vou me exprimir, mas eu mesmo não sei ainda o que vou dizer e o que vou exprimir". E se está na vida. [...]

\section{E.S.: $\mathrm{O}$ que é o corpo ontologicamente?}

ODS: Michel Henry... O primeiro a falar muito, muito bem sobre isto, é Aristóteles. No seu "Petit traité de l'âme" ("OTratado da alma"), ele tem uma maneira extraordinária de abordar a questão do corpo. Aristóteles nos diz isto: “Toda experiência sensível do corpo é uma experiência pela qual o corpo é conduzido a experimentar por ele próprio", quer dizer, toda percepção, seja como for, uma percepção de uma flor, de uma pessoa etc., não vais somente perceber uma informação que chega a ti. (...) Escuto um som, vejo asas dançado, não sei que... De acordo? Então, percebo alguma coisa. Mas ao mesmo tempo em que esta informação entra em mim, meu corpo se enrola em volta desta informação e vai viver ele mesmo qualquer coisa através desta informação. Então, o corpo no seu mesmo ser é levado a mudar e conduzido a viver a alguma coisa por si próprio, graças ao que ele percebe do mundo. Compreendes?

\section{E.S.: É para perceber diferente o mundo?}

ODS: Perceber, ver, tocar, sentir. Ou seja, toda percepção, compreenda bem, é também uma auto-revelação. Uma revelação de si para si. E uma revelação de si pelo mundo. Tu tens um enrolamento, assim, permanentemente. E é isto o grande valor 
ontológico do corpo, é que ao contrário da mesa - a mesa toca o solo, a mesa não toca o solo, a mesa está sobre o solo - mas os meus pés tocam o solo. Ou seja, que eu faço uma experiência sensível do solo me tocando e de mim tocando o solo. Assim permanentemente, tem este movimento de ir e vir do próprio corpo a partir das suas próprias percepções do mundo.

E.S.: Eu li um pouco do livro "A violência na arte".7 Eu quero entrar um pouco no tema da violência, falar um pouco de violência também... Você pode falar um pouco da violência na arte?

OS: De fato, eu cheguei a este assunto porque, frequentemente, me diziam que a minha arte era violenta, o que eu fazia era violento. E que... para mim havia confusão, foi preciso que eu me questionasse sobre isto, que eu tentasse compreender porque as pessoas viam isto como violência, se era uma violência gratuita ou se era uma violência necessária, ou se havia realmente violência ou não. Finalmente, eu refleti sobre isso, me pareceu que a violência no meu trabalho era uma violência que era feita primeiro à matéria e a mim mesmo no sentido onde a matéria não se deixa ver, tem que trabalhá-la, é necessário confrontá-la... É difícil modelá-la... Mas, por si só é difícil a desafiar, etc. Portanto, em qualquer gesto de criação, inicialmente, há uma forma de violência. Como ontem, falávamos com Ghel, ${ }^{8}$ que a dança era uma reação à gravidade, e, portanto, é uma forma de violência no que diz respeito a um estado estável. De horizontalidade. Verticalidade é uma forma de violência à horizontalidade. Podem-se dizer coisas como isto.

\section{E.S.: Uma resistência também.}

ODS: Hein? Uma resistência, sim.

NOEL, Bernard/MOREAU, Marcel/ BERGÉ, Christiane/SANDA,Paul/ VERRIÉLE,Philippe/ BRASSAT, Emmanuel/ CALAN, Rolan de. "A Violence en art". Galerie Marie Vitoux, 2007 (Nota do autor).

8

Bailarino franco-brasileiro que vive em Saint-Nazaire, França. Desenvolveu o trabalho "Danse du chaos" em parceria com Olivier De Sagazan. Neste trabalho pesquisa as interfaces entre a desfiguração e hip-hop.
E, portanto, de fato, a violência, aparece já como uma necessidade ontológica de qualquer criação. Não se pode escapar dela. E mesmo que exista uma violência, pois se sabe que... Como eu te expliquei ontem, para resistir sobre um plano termodinâmico é necessário extrair forças do exterior, e estas forças, se vai buscar em outros organismos. Portanto, para viver, se é obrigado a fazer violência com outros organismos que se vai matar para sobreviver. Portanto, a violência é uma pedra fundadora da vida. Não há vida sem violência. E se há um bom Deus na origem do mundo, é um ser horrível, pois ele concebeu as coisas assim. Ele disse a cada organismo: "você não poderá viver sem o sangue dos outros". Portanto, se Deus existe, é um horrível vampiro, uma forma assustadora de vampiro, o mestre de todos os vampiros.

Portanto isso é uma primeira coisa, a primeira constatação da existência. Portanto, a criação necessita da violência. Em seguida, há certamente nas minhas representações uma forma de violência em relação ao esquema habitual de representação das coisas. Como minha opção, minha estratégia, é de ir contra os conformismos, a partir do momento aonde você quer ir contra os conformismos, você deve ir buscar caminhos de passagens, você deve quebrar hábitos. E, portanto, há ainda uma forma de violência. Ou seja, que em relação a todos os caminhos que as pessoas geralmente buscam se diz não. Parem, não se continua por ai, agora se vai ver por aqui. E, portanto, se é obrigado a fazer violência às representações e os esquemas habituais. Em seguida, esta violência, aparece ainda em outro nível, que é a desfiguração. Estas transformações que eu tento na representação do corpo humano, são desfigurações. Ou seja, que se vê primeiramente, como violento. Ou seja, de repente se dá um grande golpe de faca no rosto de alguém, etc. se vemos desta forma, é violento, mas é uma violência gratuita, sem interesse. E é assim que a maior parte das pessoas vê. Eles pensam que eu desfigurei, porque na realidade teria tido prazer de deformar o 
rosto de alguém. O que não é de forma alguma o caso. Na minha vida eu jamais esmaguei uma mosca. Compreendes?

E.S.: Eu compreendo, eu penso também que esta violência está contra a identidade, porque você deforma a identidade.

O.D.S.: E, portanto, esta violência que toca mais as pessoas, naturalmente, porque elas estão numa forma de identificação, de projeção. Elas vêem um corpo representado, elas imaginam seu corpo violentado. Sem compreender que a arte é uma metáfora, que a arte tem por função justamente de entrar num mundo virtual, imaginário, onde muitas coisas são possíveis. E a arte é um campo de experimentação. Mas em nada, a arte é uma representação do real, onde se estaria projetando em fazer naturalmente tal ou tal coisa. Portanto, é essencialmente, aí o equívoco. É não compreender que para mim a arte é um campo de pesquisa, um campo de observação, onde eu faço manipulações como faria um geneticista, um investigador, ou, seja o que for. E, portanto, estou aqui para fazer experimentações e ver o que isso vai me produzir. O que é tal deformação, o que é suprimir o olho direito, suprimir a boca, aumentar a boca, etc... O que isso pode produzir em mim? É isto que me interessa.

Portanto, eu não trabalho apenas nesta ideia, mas naturalmente, as pessoas, grande parte delas, quando vêem um olho furado ou outro buraco feito na têmpora, elas se dizem: é sádico, que gostaria muito de fazer buracos na têmpora de alguém. Eu não acho isso, em coisas como isso. Então, de fato, eu, eu teria outra ideia, que é na medicina. Há laboratórios que se desenvolvem para estudar o desenvolvimento do embrião, e eles se dão conta, particularmente, que em nível da forma do rosto do embrião, todas as deformações que aparecem no rosto de um embrião, são deformações externas ao rosto, e que correspondem às deformações do sistema nervoso. Porque, de fato, a nível embrionário, há um mesmo tecido que se chama... endoderme, mesoderma, epiderme... Não.

\section{E.S.: A epiderme?}

O.D.S.: Não, exoderme, é um tecido embrionário que em certo momento se transforma seja em pele, ou, seja em sistema nervoso. Mas a pele, o sistema nervoso e os músculos também têm uma mesma origem embrionária. E, portanto, os médicos se deram conta que quando se vê uma criança que tem um lábio mal formado, que tem uma narina mal colocada, etc., isso corresponde, automaticamente, a uma deformação do sistema nervoso. E eles são capazes, ponto a ponto, de ver que tal deformação corresponde a algo que se passa no sistema nervoso. Tal deformação aqui corresponde a uma deformação no sistema nervoso lá. Certo?

Portanto, por uma única análise do rosto, se pode saber se o sistema nervoso é bem formado. Certo? Então minha ideia, é que: se há uma correspondência, se há uma relação entre o rosto e o sistema nervoso, se pode ver visualmente se eu transformo aqui. Eu tenho o sistema nervoso dos espectadores e aqui tenho o meu rosto, se eu faço um ponto sobre este rosto e se eu faço uma deformação sobre este rosto, eu devo poder estimular tal ou tal parte do sistema nervoso.

É mais ou menos essa a minha ideia. Portanto, na minha "performance" tenho um rosto que é muito liso. De repente, eu vou fazer um olho, isso provoca uma excitação no sistema nervoso. Outro olho, outra excitação. De repente, em seguida, uma enorme boca, isso produz ainda outra coisa no sistema nervoso, mas algo que não corresponde a nada.

E.S.: E no livro que eu li sobre violência em arte tem um tema: "Civilização do fundo dos corpos". Eu penso que é com a "Civilização do fundo dos corpos" que você sente algo que vai fazer.

O.D.S.: Sim, também. Ou seja, que esta ideia de Marcel Moreau, e esta "civilização do fundo dos corpos" estão muito próximas também de Artaud. Ou seja, que Artaud pensa que a linguagem está muito presente no teatro e que esta linguagem 
mata uma parte do aspecto plástico/físico do teatro. Ou seja, que esta parte plástico/ física que corresponde às mímicas, há milhões de pequenos movimentos do corpo, pequenas inflexões que vão sugerir algo em ti. Automaticamente, isso sugere alguma coisa. E se esta tão concentrada sobre a boca na nossa civilização ocidental, que se esquece de tudo que esta ao redor. Tu compreendes? E a "civilização do fundo dos corpos" , é mais ou menos dizer: "cala a boca e olha ao redor". Tu tens um...

E.S.: Porque não se tem necessidade de palavras para observar. Mas o que tem esta civilização?

\section{O.D.S.: O que é a civilização?}

\section{E.S.: Sim, a "civilização do fundo dos corpos".}

O.D.S.: Eh bem, a "civilização do fundo dos corpos" é justamente esta ligação que os corpos constituíram uns com os outros, após gerações e gerações e para justamente estabelecer campos de consciência. Ou seja, que cada indivíduo é um ponto de observação do mundo. Mas muitos indivíduos juntos constituem um campo muito vasto de observação e percepção do mundo. E estamos todos em interação uns com os outros, e esta "civilização do fundo dos corpos" é justamente todo este tumulto de percepções de consciência, etc., que se estabeleceu depois de gerações, e que de repente são como que riscadas pela linguagem. Porque o problema da linguagem, é que ela cortou o corpo em dois, ela disse que de um lado tem à língua, outro tem o espírito. E depois, tem tudo o que é da ordem que se pode pôr sob as palavras, que se pode classificar, organizar. E de outro lado, há uma coisa muito complicada, algo difuso, complexo, o afetivo, uma forma de sensibilidade muito complicada.

E.S.: E qual é a importância da técnica? Eu já lhe falei um pouco, mas você pode falar um pouco mais da técnica? Porque eu vejo que você corre, faz exercício, é uma forma de preparar o corpo? É também uma forma de preparação? Mas a técnica é espontânea? Tu tinhas dito: "o realismo antes era um pouco espontâneo".

O.D.S.: Antes, eu falei do caráter espontâneo quando se trabalha, é importante. Mas certamente, o corpo é um instrumento. E é meu instrumento o mais importante. Portanto, certamente, eu tento conservá-lo, eu corro todos os dias um pouco, fazer exercícios, etc., etc. Eu tenho uma preocupação com corpo e de um corpo bom... Como eu diria... Bem elástico, enfim, que responde bem ao que eu peço. E de outro lado, eu dou muita importância à presença da mão numa obra de arte. O que me toca na arte primitiva, é justamente esta presença da mão. Tu te lembras da pequena escultura que te mostrava ontem... Tu vês todas as coisas como isso foi feito, etc. Portanto, tu podes acompanhar cada momento, tu podes reviver cada momento da escultura olhando como foram postos os dedos, como isso rodeia, etc., etc. Enquanto que isso, não tem nenhuma presença de mão, isso é a morte do corpo. Isso é um corpo morto. Compreendes? E é objeto industrializado. Diz-se industrializado, mas não tem mão. A mão não está presente. Não, é totalmente feito por máquinas. E são, portanto, estes objetos mecânicos, contra corpos. E para mim, o que me comove num objeto, numa obra de arte, é esta projeção do corpo, é este "analogon" com o corpo. É a presença da mão, é a presença de uma sensibilidade, que desaparece cada vez mais de todos os objetos da nossa civilização. $\mathrm{Na}$ "civilização do fundo dos corpos", tudo não era que de corpos. Hoje, tem cada vez menos corpos. Tudo é fechado. Olhe, eu estou em contato com Elisa, mas Elisa, eu não a conheço. Elisa é quem? Como? É o quê? Etc.... Então, por azar, eu te encontro, e é muito bom. Mas muitas vezes, eu tenho 10 e-mails por dia de pessoas que eu não conheço. E eu estou em contato com eles, mas, bom... um contato muito, muito esquisito. E, portanto, vejo efetivamente que se entra num mundo onde se tem tal adoração no que diz respeito à técnica, estamos tão admirados no que diz respeito à técnica, que esquecemos esta 
coisa alucinante, olhe isso, olhe... pelo pensamento, pelo meu pensamento, eu faço levantar este braço.

E.S.: E quais são as fronteiras ou os limites do corpo humano? Em sua opinião?

O.D.S.: As fronteiras, os limites...Bom, bem, os limites do corpo humano... Eu não vejo justamente limites, ou seja, o que não tem de inconcebível no corpo humano, é justamente o fenômeno da vida em si. Quer dizer que é... o que dou como exemplo frequentemente, é que a vida, é uma dobra. A vida é uma dobra da matéria espaço/ tempo... Tens a matéria espaço/tempo. Aí está a matéria espaço/tempo. O tempo que se desdobra. E, portanto, esta matéria espaço/tempo, tu podes fazer a volta, tu podes medi-la, etc. Mas a partir do momento em que tem a vida em algum lugar, tu tens uma dobra. E o próprio da dobra, é de esconder algo. A dobra esconde alguma coisa aqui. E isto que ela esconde, ela não pode revelar a ninguém. É algo que ela guarda para si. É teu interior. Cada organismo tem seu interior.

Este interior é a sua identidade. Quando o organismo morre, ele se desdobra se torna um cadáver. Um cadáver. Um cadáver é um corpo que se desdobra que se abre, o qual se pode fazer a volta. Aqui eu não posso fazer a volta, porque eu não chego aqui. Eu posso fazer a volta de algo, mas não faço a volta daqui. Porque o que está lá é no interior, é acósmico, sem relação com o mundo sensível.

\section{E.S.: Acósmico...}

O.D.S.: Tu compreendes? O cosmos... o cosmos, as estrelas, etc. Acósmico, "A" é privativo. Certo? Portanto aqui é acósmico, tu não podes fazer a volta. E o que se passa no interior, é que tu sentes quando tu tocas estes dedos aqui com o teu lápis. Mas somente Elisa que pode sentir isso. Eu não posso saber o que tu sentes. Posso tentar reproduzir a mesma coisa, mas eu não posso saber... Tu compreendes? Isto é teu sentir a ti, ele é acósmico, ele está fora do mundo. É nisso, quando tu me perguntas quais são os limites do corpo, o corpo não tem limite. Quer dizer que no momento em que isso vive isso se passa no interior, algo, é a caixa preta. Há uma caixa preta na qual eu não posso entrar. Só a pessoa que possui - que tem esta caixa preta - pode sentir o que ela tem. Portanto, há realmente... há algo de extraordinário. É por isso que o cadáver me agrada bem, porque o cadáver guarda a marca da dobra. Isso foi dobrado, isso não é mais.

\section{E.S.: E o que é a carne humana?}

O.D.S.: Bem, a carne...

\section{E.S.: É um mistério...}

O.D.S.: Não, a carne, é o que permite justamente a formação desta interioridade. A carne... Olha isso... E de repente, isto se redobra. E isso não é esmagado pelo mundo, porque isso consegue reagir. Isso sente o mundo permanentemente. O mundo, permanentemente, ele te envia coisas, pan... pan...! Assim em todos os sentidos, e tu reages, e é esta interface. A carne é a interface, seu ponto de interrogação e o mundo. 